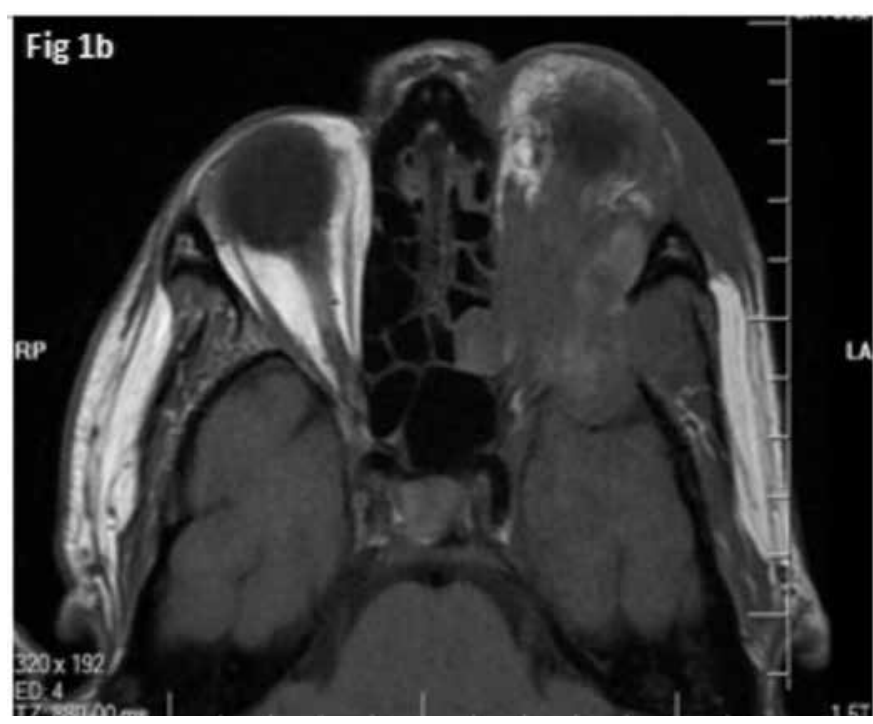

Figure $1 \mathrm{~b}$. Magnetic resonance imaging image of orbital adnexal mass.

Keywords: Primary bone lymphoma, Ocular adnexal lymphoma,

Diffuse large B-cell lymphoma

Anahtar Sözcükler: Primer kemik lenfoma, Oküler adneks lenfoma, Diffüz büyük B hücreli lenfoma

\section{Ethics}

Ethics Committee Approval: Not applicable; Informed Consent: Not applicable.

\section{Authorship Contributions}

Surgical and Medical Practices: Rafet Eren, Elif Suyanı; Concept: Rafet Eren, Ceyda Aslan, Cihan Gündoğan, Osman Yokuş, Mehmet Hilmi Doğu, Elif Suyanı; Design: Rafet Eren, Ceyda Aslan, Cihan Gündoğan, Osman Yokuş, Mehmet Hilmi Doğu, Elif Suyanı; Data Collection or Processing: Rafet Eren, Ceyda Aslan, Cihan Gündoğan, Osman Yokuş, Mehmet Hilmi Doğu, Elif Suyanı; Analysis or Interpretation: Rafet Eren, Ceyda Aslan, Cihan Gündoğan, Osman Yokuş, Mehmet Hilmi Doğu, Elif Suyanı; Literature Search: Rafet Eren, Ceyda Aslan, Cihan Gündoğan, Osman Yokuş, Mehmet Hilmi Doğu, Elif Suyanı; Writing: Rafet Eren, Ceyda Aslan, Cihan Gündoğan, Osman Yokuş, Mehmet Hilmi Doğu, Elif Suyanı.

Conflict of Interest: The authors of this paper have no conflicts of interest, including specific financial interests, relationships, and/ or affiliations relevant to the subject matter or materials included.

\section{References}

1. Messina C, Christie D, Zucca E, Gospodarowicz M, Ferreri AJ. Primary and secondary bone lymphomas. Cancer Treat Rev 2015;41:235-246.

2. Kitsoulis P, Vlychou M, Papoudou-Bai A, Karatzias G, Charchanti A, Agnantis NJ, Bai M. Primary lymphomas of bone. Anticancer Res 2006;26:325-337.

3. Ponzoni M, Govi S, Licata G, Mappa S, Giordano Resti A, Politi LS, Spagnuolo L, Di Cairano E, Doglioni C, Ferreri AJ. A reappraisal of the diagnostic and therapeutic management of uncommon histologies of primary ocular adnexal lymphoma. Oncologist 2013;18:876-884.

4. Woolf DK, Ahmed M, Plowman PN. Primary lymphoma of the ocular adnexa (orbital lymphoma) and primary intraocular lymphoma. Clin Oncol (R Coll Radiol) 2012;24:339-344

\title{
Cerebral Sinovenous Thrombosis Mimicking Intracranial Mass
}

\section{İntrakranial Kitleyi Taklit Eden Serebral Sinovenöz Tromboz}

Derya Özyörük, Neslihan Karakurt, Arzu Yazal Erdem, Suna Emir, Bahattin Tunç, Neşe Yaralı, Namık Özbek

Ankara Children's Hematology and Oncology Training and Research Hospital, Ankara, Turkey

To the Editor,

Cerebral sinovenous thrombosis is rare in children [1]. Most common signs and symptoms are seizure, lethargy, and headache $[1,2,3]$. We herein report a case diagnosed as cerebral sinovenous thrombosis mimicking an intracranial mass and presenting with increased intracranial pressure symptoms in an adolescent girl.
A 16-year-old girl was admitted to our emergency service with complaints of headache, vomiting, and confusion. Her past medical history was unremarkable. Physical examination revealed facial paralysis and motor weakness on the left side. Magnetic resonance (MR) imaging disclosed a mass $(65 \times 42 \times 55 \mathrm{~mm})$ in the right temporal lobe shifting the midline structure from right to left (Figure 1). Because of herniation findings, surgery was performed immediately. Histopathologic investigation showed 


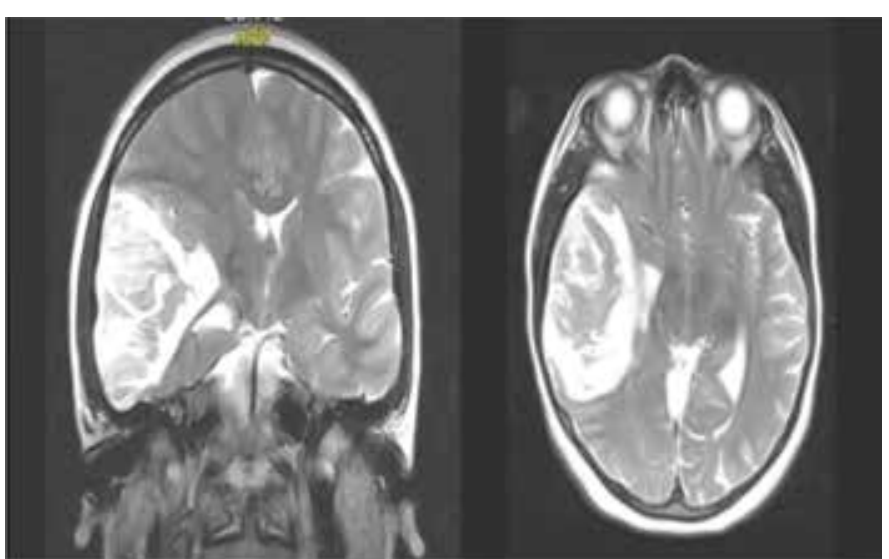

Figure 1. Cranial magnetic resonance images of the patient demonstrate a heterogeneous parenchymal lesion with increased T2 signal intensity in the right temporal lobe causing compression of the third lateral ventricle, basal ganglion, and thalamus with sylvian fissure, sulcal effacement, shifting midline structure, and significant edema.

hematoma, gliosis, inflammation, and vasculitis. The laboratory examination revealed iron deficiency anemia (white blood cells: 12×109/L, Hb: $7.2 \mathrm{~g} / \mathrm{dL}$, mean corpuscular volume: $49 \mathrm{fL}$, red cell distribution width: $20 \%$, platelets: 570×109/L, ferritin: $4.4 \mathrm{ng} / \mathrm{mL}$ ). Other hematologic tests and coagulation panels were determined to be normal. Prothrombotic markers such as protein $\mathrm{C}$, protein $\mathrm{S}$, antithrombin III, plasminogen, heparin cofactor II, factor VIII, factor XII, lipoprotein (a), fibrinogen, homocysteine, anticardiolipin IgG, lupus anticoagulant levels, prothrombin 20210G, and factor $\mathrm{V}$ Leiden were normal. Tumor markers were negative. Cranial MR venography demonstrated stasis and occlusion in the middle distal part of the transverse sinus, sigmoid sinus, and internal jugular vein. The patient had no signs of nephrotic syndrome, infection, or vasculitis. She was diagnosed with transverse sinus thrombosis and anticoagulated with low-molecular-weight heparin. Iron supplementation was administered for six months.

Cases of thrombosis presenting with signs of intracranial mass are rarely reported in the literature. Kim et al. [4] reported a 54-yearold male patient who was operated on for an intracranial tumor; however, the final diagnosis was thrombus in the aneurysm of the middle cerebral artery. In another report, a 20-month-old girl presented with rapidly progressing hemiparesis on the left side. Cranial MR revealed an abscess or glial tumor-like lesion in the right thalamus; however, pathological investigation of the stereotactic biopsy specimen did not show any signs of malignancy. On day 14 of admission, control cranial MR showed thrombosis in the superior sagittal sinus and transverse sinus [5].

The association of iron deficiency anemia with sinus thrombosis has been reported previously in children [6]. Although secondary thrombocytosis has been implicated in cerebral venous sinus thrombosis associated with iron deficiency, two cases with normal platelet count have also been described [7]. As not all cases of iron-related thrombotic events occur in patients with concomitant high platelet counts, other pathogenic mechanisms have been proposed. One of these explanations is that iron deficiency may contribute to a hypercoagulable state by affecting blood flow patterns within the vessels because of reduced deformability and increased viscosity of microcytic red blood cells. Furthermore, anemic hypoxia secondary to iron deficiency has been suggested to precipitate situations of increased metabolic stress, in particularly in vulnerable areas of the brain supplied by end arteries [8]. In our patient, iron deficiency may also have contributed to the development of thrombosis.

In conclusion, cerebral sinovenous thrombosis associated with increased intracranial pressure symptoms may mimic intracranial masses in children.

Keywords: Intracranial mass, Cerebral sinovenous thrombosis, Increased intracranial pressure

Anahtar Sözcükler: Intrakranial kitle, Serebral sinovenöz tromboz, Artmış intrakranial basınç

\section{References}

1. Hedlund GL. Cerebral sinovenous thrombosis in pediatric practice. Pediatr Radiol 2013;43:173-188.

2. Suppiej A, Gentilomo C, Saracco P, Sartori S, Agostini M, Bagna R, Bassi B, Giordano P, Grassi M, Guzzetta A, Lasagni D, Luciani M, Molinari AC, Palmieri A, Putti MC, Ramenghi LA, Rota LL, Sperli D, Laverda AM, Simioni P. Stroke working group of the Italian Registry of Pediatric Thrombosis. Paediatric arterial ischaemic stroke and cerebral sinovenous thrombosis. First report from the Italian Registry of Pediatric Thrombosis (R.I.T.I., Registro Italiano Trombosi Infantili). Thromb Haemost 2015;113:1270-1277.

3. Ichord RN, Benedict SL, Chan AK, Kirkham FJ, Nowak-Göttl U. International Paediatric Stroke Study Group. Paediatric cerebral sinovenous thrombosis: findings of the International Paediatric Stroke Study. Arch Dis Child 2015;100:174-179.

4. Kim YJ, Jeun SS, Park JH. Thrombosed large middle cerebral artery aneurysm mimicking an intra-axial brain tumor: case report and review of literature. Brain Tumor Res Treat 2015;3:39-43.

5. Haug V, Linder-Lucht $M$, Zieger B, Korinthenberg $R$, Mall V, Mader I. Unilateral venous thalamic infarction in a child mimicking a thalamic tumor. J Child Neurol 2009;24:105-109.

6. Sébire G, Tabarki B, Saunders DE, Leroy I, Liesner R, Saint-Martin C, Husson $B$, Williams AN, Wade A, Kirkham FJ. Cerebral venous sinus thrombosis in children: risk factors, presentation, diagnosis and outcome. Brain 2005;128:477-489.

7. Kinoshita $Y$, Taniura $S$, Shishido $H$, Nojima T, Kamitani $H$, Watanebe T. Cerebral venous sinus thrombosis associated with iron deficiency: two case reports. Neurol Med Chir (Tokyo) 2006;46:589-593.

8. Franchini M, Targher G, Montagnana M, Lippi G. Iron and thrombosis. Ann Hematol 2008;87:167-173. 